\title{
PENGETAHUAN GIZI DAN POLA ASUH IBU ANAK BALITA GIZI KURANG DI KELURAHAN PASTEUR KECAMATAN SUKAJADI BANDUNG
}

\author{
Sri Subekti \\ Program Studi Pendidikan Tata Boga PKK FPTK UPI \\ Jl. Dr.Setiabudhi No. 207 Bandung 40154 \\ sris_upi@yahoo.co.id \\ Cica Yulia \\ Program Studi Pendidikan Tata Boga PKK FPTK UPI \\ Jl. Dr.Setiabudhi No. 207 Bandung 40154 \\ cha_ulia@yahoo.com
}

\begin{abstract}
Abstrak : Tujuan yang hendak di capai dalam penelitian ini adalah : 1) untuk mengetahui pengetahuan gizi dan kesehatan dari ibu yang memiliki anak dengan status gizi kurang; 2) untuk mengetahui pola asuh makan dan kesehatan yang diterapkan oleh ibu yang memiliki anak dengan status gizi kurang dan 3) untuk menganalisis hubungan antara pengetahuan gizi dan kesehatan terhadap pola asuh yang diterapkan oleh ibu. Metode yang dipergunakan dalam penelitian ini adalah Cross-Sectional. Berdasarkan hasil penelitian yang telah dilakukan oleh peneliti pengetahuan gizi dan kesehatan Ibu balita lebih dari setengahnya berada pada kategori sedang. Pola asuh makan lebih dari setengah dari ibu balita termasuk dalam kategori cukup baik. Sedangkan untuk pola asuh kesehatan ibu balita berada pada kategori baik. Status gizi anak balita yang diukur dengan antropometri,umumnya berada pada kategori normal. Uji korelasi spearman mendapatkan hasil bahwa terdapat hubungan yang positif dan signifikan dan dapat disimpulkan bahwa semakin tinggi skor pengetahuan gizi ibu maka pola asuh makan yang diberikan ibu kepada anak balitanya akan semakin baik pula.
\end{abstract}

Kata kunci: Pengetahuan gizi dan kesehatan, Pola asuh, Balita.

\begin{abstract}
Nutrition knowledge is principal issues related to various nutritional problems that occur in Indonesia. Maternal role in children's growth and development is very dominant, that is in caring for and educating them. Parenting patterns applied by the mother can affect the growth of the children, especially the nutritional status. Goals to be achieved in this study are: 1) to inquire nutrition and health knowledge of mothers with malnutrition children; 2) to examine food and health parenting pattern applied by mothers with malnutrition children and 3 ) to analyze the relationship between nutrition and health knowledge and parenting pattern implemented by the mother. The method used in this study is the Cross-Sectional. The results show that more than half of mothers' nutrition and health knowledge is in medium category. More than half of mothers' food parenting pattern is in fairly good category. Whereas, mothers' health parenting pattern is in good category. Toddlers' nutritional status, as measured using anthropometry, is generally in normal category. Spearman correlation test results state that there is a positive and significant relationship, and thus it can be concluded that the higher the mother's nutrition knowledge score, the better the food parenting pattern.
\end{abstract}

Keywords: nutrition and health knowledge, parenting pattern, toddlers. 


\section{PENDAHULUAN}

Anak merupakan kelompok yang paling rentan terhadap gangguan kesehatan dan gizi karena pada masa ini masih terjadi proses pertumbuhan dan perkembangan yang memerlukan zat-zat gizi dalam jumlah yang besar sedangkan pada masa ini kelangsungan serta kualitas hidup anak sangat tergantung pada penduduk dewasa terutama ibu atau orangtuanya. Gambaran masalah kesehatan anak di Indonesia ditandai dengan masih tingginya angka kejadian penyakit dan gangguan gizi yang disertai dengan kondisi lingkungan fisik dan sosial yang belum optimal menunjang kesehatan.

Gizi buruk atau gizi kurang yang dialami oleh anak akan membawa dampak yang negatif terhadap pertumbuhan dan perkembangannya. Nancy dan Arifin (2005) mengemukakan, konsekuensi dari gizi buruk adalah lost generation, karena gizi buruk bukan hanya menjadi stigma yang ditakuti, hal ini tentu saja terkait dengan dampak terhadap sosial ekonomi keluarga maupun negara. Dampak jangka pendek gizi buruk terhadap perkembangan anak adalah anak menjadi apatis, mengalami gangguan bicara dan gangguan perkembangan yang lain. Sedangkan dampak jangka panjang adalah penurunan skor tes IQ, penurunan perkembangan kognitif, penurunan integrasi sensori, gangguan pemusatan perhatian, gangguan penurunan rasa percaya diri dan tentu saja merosotnya prestasi akademik di sekolah. Gizi kurang berpotensi menjadi penyebab kemiskinan melalui rendahnya kualitas sumber daya manusia dan produktivitas.

Untuk mencapai status gizi yang baik diperlukan pangan yang mengandung zat gizi cukup dan aman untuk dikonsumsi. Florentino et al. (1987), mengemukakan pendapat bahwa salah satu faktor yang mempengaruhi status gizi adalah konsumsi pangan yang juga sangat dipengaruhi kebiasaan makan. Hasil penelitian yang dilakukan oleh Florentino et al. (1987) menyimpulkan bahwa pengetahuan ibu tentang gizi berhubungan positif dengan cara ibu memilih jenis makanan yang beragam yang dapat mempengaruhi konsumsi makanan dan pada akhirnya dapat berpengaruh terhadap peningkatan status gizi anggota keluarga.

Berdasarkan kerangka konsep UNICEF (1990), pengetahuan gizi dan kesehatan ibu merupakan pokok permasalahan di masyarakat yang dapat menyebabkan terjadinya kurang gizi. Dari kurangnya pengetahuan tentang gizi 
dan kesehatan maka akan berpengaruh terhadap pola asuh anak yang tidak memadai, sanitasi dan air bersih / pelayanan kesehatan dasar yang tidak memadai dan tidak cukupnya persediaan pangan. Jelas sudah bahwa seorang ibu mempunyai peranan penting dalam menentukan status gizi yang baik bagi anakanaknya sehingga anak tersebut dapat tumbuh dan berkembang menjadi insan yang berkualitas.

Rumusan masalah dalam penelitian ini adalah bagaimanakah hubungan pengetahuan gizi dan kesehatan dengan pola asuh makan dan kesehatan yang diterapkan oleh ibu yang memiliki anak berstatus gizi kurang. Adapun tujuan penelitian yang hendak dicapai adalah untuk mengetahui : 1) pengetahuan gizi dan kesehatan dari ibu yang memiliki anak dengan status gizi kurang; 2) untuk mengetahui pola asuh makan dan kesehatan yang diterapkan oleh ibu yang memiliki anak dengan status gizi kurang dan 3) untuk menganalisis hubungan antara pengetahuan gizi dan kesehatan terhadap pola asuh yang diterapkan oleh ibu.

Hasil penelitian ini diharapkan dapat memberikan gambaran mengenai pengetahuan gizi dan kesehatan, pola asuh makan dan kesehatan, serta status gizi anak balita di Kelurahan Pasteur Kecamatan Sukajadi Bandung. Disamping itu hasil yang diperoleh dari penelitian ini dapat dijadikan data awal untuk diadakan penelitian lebih lanjut. Diharapkan pula hasil penelitian ini dapat memberikan masukan dan informasi khususnya bagi pihak Posyandu Kelurahan Pasteur Kecamatan Sukajadi Bandung dalam menentukan kebijakan dan program yang tepat khususnya dalam meningkatkan status gizi anak balita di Kelurahan Pasteur Kecamatan Sukajadi Bandung.

Pengetahuan adalah segala sesuatu yang mencakup ingatan akan hal-hal yang pernah dipelajari dan disimpan dalam ingatan. Hal-hal itu dapat meliputi fakta, kaidah dan prinsip, serta metode yang diketahui (Winkel 2007). Pengetahuan gizi merupakan kemampuan seseorang untuk mengingat kembali kandungan gizi makanan, sumber serta kegunaan zat gizi tersebut di dalam tubuh. Suhardjo et al. (1986) mengemukakan bahwa suatu hal yang meyakinkan tentang pengetahuan gizi di dasarkan pada tiga kenyataan yaitu :

1. Kesehatan dan kesejahteraan sangat dipengaruhi oleh status gizi yang cukup. 
2. Setiap orang akan cukup gizi jika makanan yang dimakannya mampu menyediakan zat gizi yang diperlukan untuk pertumbuhan tubuh yang optimal, pemeliharaan dan energi.

3. Ilmu gizi memberikan fakta-fakta yang perlu sehingga penduduk dapat belajar menggunakan pangan dengan baik bagi kesejahteraan gizi.

Pengetahuan gizi merupakan pokok permasalahan yang terjadi di masyarakat terhadap berbagai masalah gizi yang terjadi di Indonesia. Khumaidi (1989) mengemukakan bahwa masalah gizi yang terjadi di pedesaan salah satunya dipengaruhi oleh pengetahuan gizi ibu yang sangat rendah, para ibu tidak mengetahui cara memasak dan menghidangkan makanan agar anaknya tidak bosan. Pengetahuan ibu tentang memilih makanan yang bernilai gizi baik juga masih sangat rendah. Selain itu pengetahuan ibu tentang cara pengolahan makanan yang baik juga masih sangat kurang.

Secara tidak langsung pengetahuan gizi ibu akan mempengaruhi status gizi anak balita. Apooh dan Krekling (2005) mengemukakan bahwa pengetahuan gizi ibu sangat berhubungan dengan status gizi anak balita. Moehji (1992) mengemukakan bahwa ketidaktahuan seseorang akan hubungan makanan dan kesehatan tidak hanya terjadi pada orang yang berstatus sosial kurang, tetapi juga banyak dijumpai pada orang-orang yang mempunyai penghasilan yang cukup banyak. Sehingga dengan keadaan ini masalah gizi tidak hanya timbul pada orang-orang miskin tetapi pada orang-orang yang tergolong kaya juga bisa terjadi.

Salah satu faktor yang mempengaruhi status gizi anak balita adalah pengasuhan yang diberikan oleh orang tuanya. Menurut kerangka UNICEF (1990) pola pengasuhan yang tidak memadai dapat mempengaruhi status gizi anak balita. Engle (1992) mengemukakan bahwa pola pengasuhan ibu merupakan penyebab tidak langsung dan merupakan determinan bagi status gizi anak yang secara langsung berpengaruh pada pertumbuhan anak.

FAO/WHO (1992) mendefinisikan pengasuhan sebagai suatu kesepakatan dalam rumah tangga dalam hal pengalokasian waktu, perhatian dan dukungan untuk memenuhi kebutuhan fisik, mental dan sosial dalam rangka tumbuh kembang anak dan anggota keluarga lainnya. Engle et al. (1996) mengemukakan pengasuhan ini biasanya di lakukan oleh wanita yang meliputi (1) pengasuhan 
untuk wanita, seperti menyediakan waktu istirahat yang cukup atau meningkatkan intik makanan selama masa kehamilan; (2) pemberian ASI dan makanan pendamping ASI bagi anak baduta; (3) stimulasi psikososial anak dan pemberian dukungan untuk tumbuh kembang anak; (4) praktek penyimpanan dan persiapan makanan; (5) praktek higiene dan (6) perawatan anak selama mengalami sakit, termasuk diagnosa penyakit dan pengadopsian praktek kesehatan di rumah.

Range (1997), mengemukakan bahwa pola pengasuhan dapat dikelompokkan menjadi empat yaitu : (1) pola asuh makan (2) pola asuh higiene dan kesehatan (3) pola asuh yang berhubungan dengan psikososial dan (4) pengasuhan untuk ibu dan sistem dukungan sosial. Range (1997) berpandangan bahwa ke empat aspek tersebut akan memberikan pengaruh terhadap konsumsi zat gizi dan terjadinya penyakit, kedua hal tersebut pada akhirnya akan mempengaruhi status gizi.

Pola asuh makan yang diberikan oleh ibu akan sangat berpengaruh terhadap status gizi anak. Karyadi (1985) mendefinisikan pola asuh makan sebagai praktek-praktek pengasuhan yang diterapkan oleh ibu kepada anak yang berkaitan dengan cara dan situasi makan. Jumlah dan kualitas makanan yang dibutuhkan untuk konsumsi anak penting sekali dipikirkan, direncanakan, dan dilaksanakan oleh ibu atau pengasuhnya. Pola asuh makan anak akan selalu terkait dengan pemberian makan yang akhirnya akan memberikan sumbangan terhadap status gizinya.

Engle, Menon dan Haddad (1996) mengemukakan bahwa dalam perilaku pemberian makanan kepada anak balita ada beberapa aspek yang harus diperhatikan, diantaranya yaitu :

1. Penyesuaian metode pemberian makan dengan kemampuan psikomotor anak.

2. Pemberian makanan yang responsif, termasuk dorongan untuk makan, memperhatikan nafsu makan anak, waktu pemberian, kontrol terhadap makanan antara anak dan pemberi makan, dan hubungan yang baik dengan anak selama memberi makan.

3. Situasi pemberian makan, termasuk bebas gangguan, waktu pemberian makan yang tertentu, serta perhatian dan perlindungan selama makan. 
Pola Asuh makan anak balita yang efektif akan berkontribusi terhadap pengurangan kasus gizi buruk pada anak balita yang masih merupakan empat masalah gizi utama yang dihadapi Indonesia.

Pola asuh kesehatan merupakan faktor yang dapat mempengaruhi status kesehatan anak balita. Pola asuh kesehatan adalah cara dan kebiasaan orang tua/ keluarga melayani kebutuhan kesehatan anak balita. Engle et al. (1996) mengemukakan bahwa salah satu pola asuh yang berhubungan dengan kesehatan dan status gizi anak balita adalah pola asuh kesehatan. Pola asuh ini meliputi pola asuh yang sifatnya preventif seperti pemberian imunisasi maupun pola asuh ketika anak dalam keadaan sakit.

Range et al. (1997) mengemukakan bahwa dalam pola asuh kesehatan tidak terlepas juga dari praktek higiene yang diterapkan oleh ibu. Praktek higiene yang mendukung dalam pola asuh kesehatan diantaranya adalah kebiasan buang air besar, kebiasaan mencuci tangan, kebersihan makanan dan akses terhadap fasilitas kesehatan yang modern.

Balita adalah anak yang berusia di bawah lima tahun. Biasanya anak balita belum bersekolah sehingga sering disebut juga dengan istilah anak usia pra sekolah. Masa balita merupakan masa terpenting dalam kehidupan. Azwar (2004) mengemukakan bahwa masa balita merupakan periode emas, karena pada masa ini terjadi pertumbuhan dan perkembangan otak yang optimal terlebih lagi pada periode dua tahun pertama kehidupan seorang anak.

Status gizi adalah ekspresi dari keadaan keseimbangan dalam bentuk variabel tertentu, atau perwujudan dari nutriture dalam bentuk variabel tertentu (Supariasa 2002). Menurut Standfield dan Hui (2003) status gizi adalah keadaan tubuh yang diakibatkan oleh konsumsi dan penggunaan (utilization) zat gizi. Status gizi balita sangat dipengaruhi oleh berbagai faktor diantaranya yaitu konsumsi pangan atau makanan. Selain faktor konsumsi makanan, status gizi balita dipengaruhi juga oleh faktor infeksi. Infeksi yang terjadi pada balita akan memperburuk status gizi balita. Hal ini dikarenakan pada saat balita mengalami infeksi biasanya nafsu makan akan hilang dan pada kejadian tertentu, keadaan infeksi dapat menyebabkan malabsorpsi, sehingga zat gizi yang berasal dari makanan tidak dapat diserap dengan baik oleh tubuh akibatnya status gizi akan 
semakin memburuk. Penilaian status gizi balita dapat dilakukan dengan berbagai cara. Menurut Gibson (2005) metode penilaian status gizi terdiri dari :

1. Metode Konsumsi makanan : tahapan pertama defisiensi gizi diidentifikasi dengan metode penilaian konsumsi makanan.

2. Metode Laboratorium : beberapa tahapan perkembangan keadaan defisiensi gizi dapat diidentifikasi dengan metode laboratorium.

3. Metode Antropometri : merupakan metode yang menggunakan pengukuranpengukuran dimensi fisik dan komposisi tubuh.

4. Metode klinis : riwayat medis dan pengujian fisik merupakan metode klinis yang digunakan untuk mendeteksi tanda-tanda dan gejala-gejala yang berhubungan dengan malnutrisi.

5. Metode ekologi : penilaian gizi seringkali melibatkan pengumpulan informasi tentang faktor-faktor yang diketahui dapat mempengaruhi status gizi penduduk, seperti data ekonomi dan sosio demografi, praktek-praktek budaya; kepercayaan-kepercayaan tentang makanan, harga pangan; pemasaran, distribusi dan penyimpanan pangan, serta statistik vital dan kesehatan.

Dari kelima metode penilaian status gizi, metode antropometri merupakan cara paling sederhana dan praktis. Supariasa (2002) mengemukakan bahwa antropometri merupakan penilaian status gizi yang sederhana karena prosedurnya sederhana, aman dan dapat dilakukan dalam jumlah sampel yang besar. Selain itu alatnya murah, mudah dibawa, tahan lama, dapat dipesan dan dibuat didaerah setempat. Antropometri adalah yang berhubungan dengan berbagai macam pengukuran dimensi tubuh dan komposisi tubuh dari berbagai tingkat umur dan tingkat gizi (Jellife \&Jellife 1989).

\section{METODE PENELITIAN}

Desain penelitian adalah Cross-sectional. Penelitian ini dilakukan di Kelurahan Pasteur Kecamatan Sukajadi Bandung Provinsi Jawa Barat. Penelitian dilakukan selama lima bulan dari bulan Juni sampai November 2010.

Data yang dikumpulkan dari penelitian ini adalah data primer. Data primer meliputi: pola asuh makan dan kesehatan anak balita pengetahuan gizi dan kesehatan ibu, yang dikumpulkan dengan metode wawancara menggunakan 
kuesioner. Data status gizi dikumpulkan dengan cara pengukuran antropometri berat badan yang menggunakan timbangan injak digital Camry dengan ketelitian $0,1 \mathrm{~kg}$ dan pengukuran tinggi badan menggunakan microtoice dengan ketelitian $0,1 \mathrm{~cm}$. Untuk anak balita yang berumur dibawah satu tahun, pengukuran panjang badan dilakukan dengan mengukur panjang badan menggunakan alat pengukur panjang badan.

Data yang diperoleh dianalisis secara deskriptif dan statistik dengan menggunakan program Excell, WHO Antro 2005, dan SPSS versi 14.0. Untuk menganalisis hubungan pola asuh makan dan kesehatan, pengetahuan gizi dan kesehatan, dengan status gizi balita dipergunakan uji korelasi spearman.

\section{HASIL PENELITIAN}

Umur responden diklasifikasikan berdasarkan kelompok usia 20- 30 tahun dan 31-41 tahun. Berdasarkan Klasifikasi tersebut, maka sebaran umur ibu adalah $36 \%$ berada pada usia 20-30 tahun dan $64 \%$ berada pada usia 31-41 tahun.

Tabel 1. Sebaran umur ibu

\begin{tabular}{lccc}
\hline \multirow{2}{*}{ Umur } & \multicolumn{2}{c}{ Ibu } \\
\cline { 2 - 3 } & Jumlah & $\%$ \\
\hline 20-30 & Tahun & 16 & 36 \\
& Tahun & 28 & 64 \\
& & \\
\hline Total & 44 & 100
\end{tabular}

Pendidikan responden dilihat berdasarkan tingkat pendidikan yang telah di selesaikan oleh responden, yaitu yang terdiri dari Tamat SD, tamat SMP, tamat SLTA dan tamat S1. Berikut ini adalah sebaran pendidikan responden.

Tabel 2. Sebaran Tingkat pendidikan Responden

\begin{tabular}{lcc}
\hline \multirow{2}{*}{ Tingkat Pendidikan } & \multicolumn{2}{c}{ Ibu } \\
\cline { 2 - 3 } & Jumlah & $\%$ \\
\hline SD & 1 & 2 \\
SMP & 10 & 22 \\
SLTA & 26 & 59 \\
D1 & 2 & 4 \\
D3 & 3 & 6 \\
S1 & 2 & 4 \\
\hline Total & 44 & 100 \\
\hline
\end{tabular}


Pada umumnya responden adalah ibu rumah tangga hal ini dapat dilihat dari sebaran persentase yang tinggi yaitu $88 \%$ sedangkan sisanya $11 \%$ berprofesi sebagai pegawai swasta. Berikut adalah sebaran pekerjaan responden.

Tabel 3 Sebaran Pekerjaan Responden

\begin{tabular}{lcc}
\hline \multicolumn{1}{c}{ Jenis Pekerjaan } & Jumlah & $\%$ \\
\hline Ibu rumah tangga & 39 & 88 \\
Pegawai swasta & 5 & 12 \\
\hline Total & 44 & 100
\end{tabular}

Anak balita yang diambil pada penelitian ini adalah anak yang berumur 6 bulan hingga 60 bulan. Kategori pengambilan umur ini didasarkan pada pertimbangan bahwa kelompok umur ini termasuk kelompok rawan (Vulnerable group) terhadap berbagai penyakit sehingga dapat mempengaruhi status gizinya. Kategori umur balita di kategorikan menjadi dua yaitu 1-3 tahun dan 3-5 tahun.

Tabel 4 Sebaran Umur Anak Balita

\begin{tabular}{ccc}
\hline Umur (tahun ) & Jumlah & $\%$ \\
\hline 1-3 tahun & 28 & 63 \\
$3-5$ tahun & 16 & 37 \\
\hline Total & 44 & 100 \\
\hline
\end{tabular}

Berikut adalah tabel Jenis kelamin anak balita, lebih dari setengahnya adalah (56\%) perempuan dan kurang dari setengahnya (43\%) adalah laki-laki.

Tabel 5 Sebaran Umur Anak Balita

\begin{tabular}{lcc}
\hline \multicolumn{1}{c}{ Jenis Kelamin } & Jumlah & $\%$ \\
\hline Perempuan & 25 & 56 \\
Laki-laki & 19 & 44 \\
\hline Total & 44 & 100
\end{tabular}

Pengetahuan gizi dan kesehatan ibu balita diukur dengan menjumlahkan skor yang diperoleh dengan skor maksimal 40 poin, kemudian dikategorikan pengetahuan gizi dan kesehatan ibu baik apabila > 80\%, sedang 60-80\% dan kurang $<60 \%$.

Rata-rata skor pengetahuan gizi dan kesehatan ibu Balita adalah 30,06 \pm 3,02. Skor tertinggi adalah 36 dan skor terendah adalah 22. (Gambar 1). 


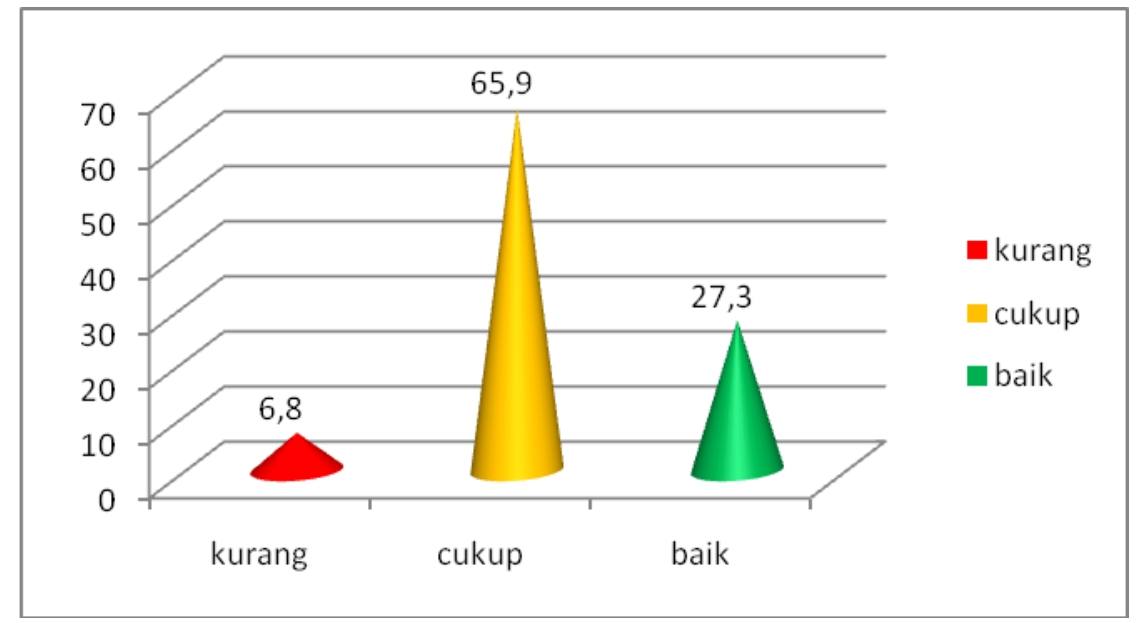

Gambar 1 Persentase pengetahuan gizi dan Kesehatan Ibu Balita

Persentase pengetahuan gizi dan kesehatan terbanyak adalah pada kategori sedang dengan persentase $65,9 \%$. Ibu yang telah mempunyai pengetahuan gizi \& kesehatan kategori baik sebanyak 27,3\% dan sisanya 6,8 \% masih dalam kategori kurang

Pengasuhan adalah kesepakatan dalam rumah tangga dalam hal pengalokasian waktu, perhatian, cinta dan keterampilan untuk memenuhi kebutuhan fisik, mental dan sosial.

Pola asuh makan yang diukur dalam penelitian ini meliputi praktek pemberian ASI, praktek pemberian susu formula, praktek pemberian makanan pendamping ASI. Pembiasaan konsumsi makanan sumber protein hewani, sumber protein nabati, buah-buahan dan sayuran. Selain itu pola asuh makan diukur melalui situasi dan kondisi pemberian makanan yang meliputi jadual pemberian makan, perhatian dan perlindungan selama anak makan, waktu pemberian makan, serta dukungan anggota keluarga dalam pola asuh makan. Kategori pola asuh makan terdiri dari tiga, yaitu kategori baik $>80 \%$, cukup baik $60-80 \%$ dan kurang baik $<60 \%$.

Hasil penelitian ini menunjukkan bahwa rata-rata skor pola asuh makan ibu balita adalah 18,49 \pm 2,45 dengan nilai minimum 10 dan nilai maksimum 15 . Persentase kategori pola asuh makan seperti pada gambar 2. 


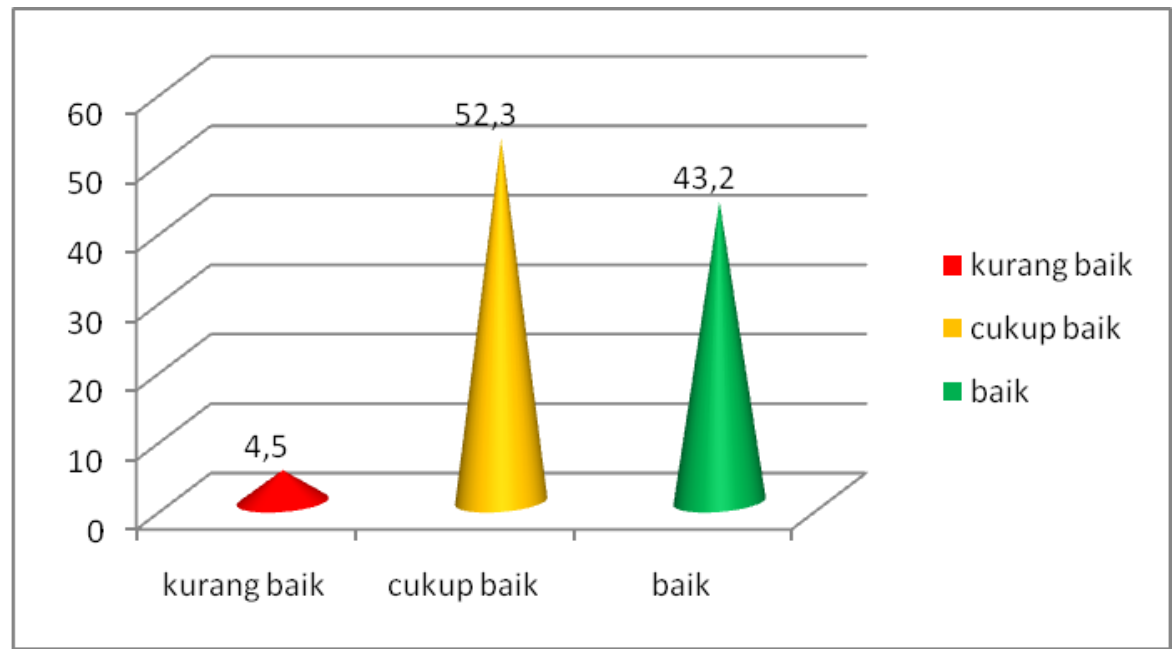

Gambar 2. Persentase Pola Asuh Makan

Hasil penelitian menunjukkan bahwa pola asuh kesehatan yang diberikan ibu kepada anak balitanya berada pada dua kategori yaitu baik dengan persentase sebesar 90,9\% dan cukup baik dengan persentase $9,1 \%$.

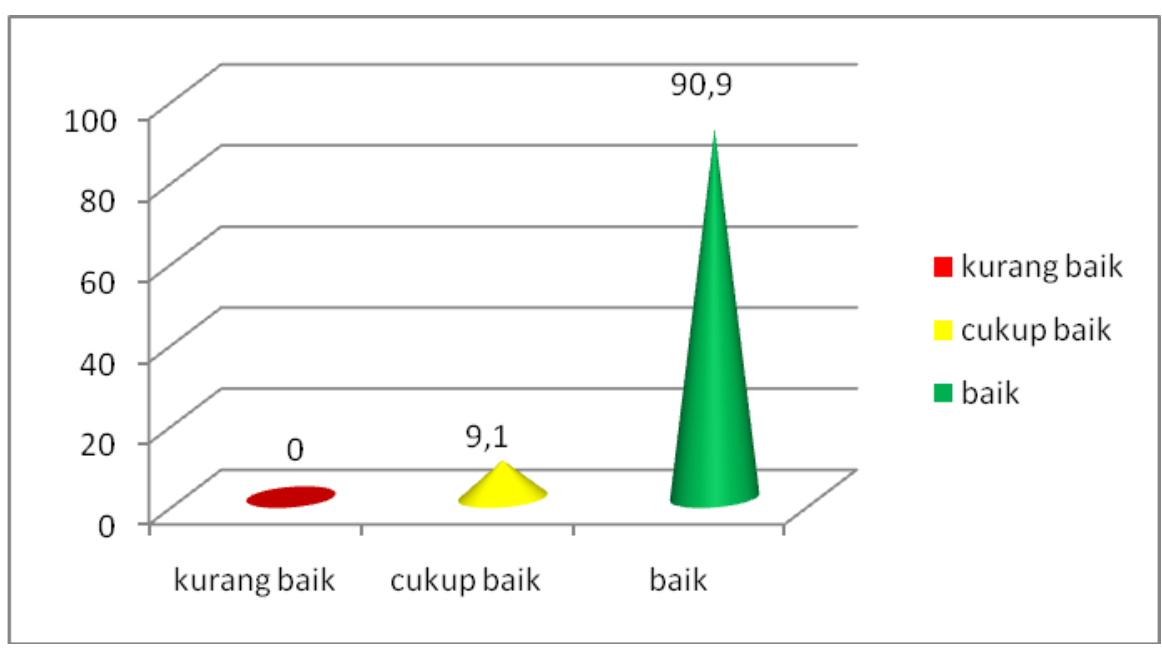

Gambar 3. Persentase Pola Asuh Kesehatan

Dari gambar di atas dapat di simpulkan bahwa hampir seluruh ibu balita sudah memberikan pola asuh kesehatan yang baik terhadap anak balitanya. Beberapa indikator yang menjadi penilaian dalam pola asuh kesehatan diantaranya yaitu menimbang anak balita setiap bulannya. Hal ini dilakukan guna melihat pertumbuhan dari anak balita tersebut, karena dengan melihat naik atau turunnya timbangan berat badannya merupakan salah satu indikator apakah anak tersebut sehat atau sakit. Hasil penelitian menunjukkan bahwa seluruh ibu balita (100\%) selalu menimbang anak balitanya setiap bulan. 
Indikator lain dalam pola asuh kesehatan adalah pemberian imunisasi kepada anak balita. Hasil penelitian menunjukkan bahwa 97,7 \% ibu balita memberikan imunisasi kepada anaknya dan sebanyak 2,3\% tidak mengimunisasi anak balitanya.

Status gizi anak balita dalam penelitian ini dinilai berdasarkan antropometri dengan indeks berat badan menurut umur $(\mathrm{BB} / \mathrm{U})$, tinggi badan menurut umur $(\mathrm{TB} / \mathrm{U})$ dan berat badan menurut tinggi badan (BB/TB) berdasarkan indeks yang telah direkomendasikan oleh WHO (1995). Pengolahan data menggunakan software WHO Antro.

Hasil penelitian menunjukkan bahwa status gizi balita berdasarkan indeks $\mathrm{BB} / \mathrm{U}$ menunjukkan bahwa rata-rata nilai Z-skor adalah $0,13 \pm 1,37$ dengan nilai Z-skor terendah -2,08 dan nilai z skor tertinggi 3,41. Status gizi balita dengan menggunakan indek TB/U menunjukkan bahwa rata-rata nilai Z-skor adalah -0,57 $\pm 1,65$ dengan nilai Z-skor terendah $-3,78$ dan tertinggi 2,95 . Sedangkan untuk rata-rata nilai Z-skor dengan menggunakan indeks BB/TB mendapatkan nilai ratarata $0,23 \pm 1,37$ dengan nilai Z-skor terendah -2,71 dan tertinggi 2,86.

Indeks berat badan menurut umur memberi gambaran tentang massa tubuh dan menggambarkan keadaan status gizi pada masa kini.

Tabel 7. Persentase Status Gizi Anak Balita Berdasarkan Indeks BB/U

\begin{tabular}{lcc}
\hline \multicolumn{1}{c}{ Z-Skor } & Jumlah & $\%$ \\
\hline $\mathrm{Z}-$ skor $<-2$ & 1 & 2,3 \\
$\mathrm{Z}-$ skor $>2$ & 3 & 6,8 \\
$\mathrm{Z}-$ skor $(-2)-2$ & 40 & 90,9 \\
\hline Total & 44 & 100 \\
\hline
\end{tabular}

Tabel 7 menunjukkan bahwa sebagian besar anak baita mempunyai status gizi yang normal, karena nilai Z-skor nya berada pada (-2) - 2, sebanyak 90,9\%. Sedangkan $6,8 \%$ berada pada kategori Overweight dan $2,3 \%$ pada kategori underweight.

Supariasa (2002) mengemukakan bahwa tinggi badan merupakan antropometri yang menggambarkan keadaan pertumbuhan skeletal. 
Tabel 8. Persentase Status Gizi Anak Balita Berdasarkan Indeks TB/U

\begin{tabular}{lcc}
\hline \multicolumn{1}{c}{ Z - Skor } & Jumlah & $\%$ \\
\hline Z-skor $<-2$ & 7 & 15,9 \\
Z- skor $>2$ & - & - \\
Z-skor $(-2)-2$ & 37 & 84,1 \\
\hline Total & 44 & 100 \\
\hline
\end{tabular}

Tabel 8 menunjukkan bahwa lebih dari setengah anak balita berada pada kategori normal. Sebanyak $84,1 \%$ berada pada Z-skor (-2) - 2. Sedangkan sisanya $15,9 \%$ berada pada kategori stunting.

Dalam keadaan normal perkembangan berat badan akan searah dengan pertambahan tinggi badan dengan kecepatan tertentu. Indeks BB/TB merupakan indikator yang dipergunakan untuk menilai status gizi masa kini, apabila data umur yang akurat tidak tersedia (Supariasa 2002).

Tabel 9. Persentase Status Gizi Anak Balita Berdasarkan Indeks BB/TB

\begin{tabular}{lcc}
\hline \multicolumn{1}{c}{ Z-Skor } & Jumlah & $\%$ \\
\hline wasting & 4 & 9,1 \\
Overweight & 1 & 2,3 \\
Normal & 39 & 88,6 \\
\hline Total & 44 & 100 \\
\hline
\end{tabular}

Tabel 9 menunjukkan bahwa pada indeks berat badan menurut tinggi badan, pada umumnya anak balita berada pada kategori normal $(88,6 \%)$, sebanyak 9,1\% berada pada kategori wasting sedangkan sisanya sebanyak 2,3\% masuk ke dalam kategori overweight. Hasil penelitian menunjukkan bahwa prevalensi wasting anak balita sebesar 9,1\%. Dengan persentase 9,1\% dapat disimpulkan anak balita tersebut mengalami malnutrisi. Hal ini seperti dijelaskan oleh WHO (1995) beratnya masalah malnutrisi dikatakan ada apabila prevalensi wasting mencapai lebih dari $5 \%$.

Uji korelasi spearman mendapatkan hasil bahwa terdapat hubungan yang positif dan signifikan antara pengetahuan gizi dengan pola asuh makan ibu balita ( $\mathrm{r}=0,49 ; \mathrm{P}<0,01)$. Dapat disimpulkan bahwa semakin tinggi skor pengatahuan gizi ibu maka pola asuh makan yang diberikan ibu kepada anak balitanya akan semakin baik pula. 


\section{PEMBAHASAN}

Hasil penelitian menunjukkan bahwa pengetahuan gizi dan kesehatan ibu balita, maka kategori yang paling banyak adalah kategori sedang. Hal ini disebabkan karena sebagian besar ibu balita belum mengetahui tentang sumber pangan, kegunaan zat gizi di dalam tubuh dan pengetahuan tentang ASI \& MPASI serta belum mengetahui tentang tanda-tanda dan penyebab penyakit, pertolongan pertama ketika anak menunjukkan gejala sakit dan program kesehatan dari pemerintah.

Hasil tes pengetahuan yang di lakukan menunjukkan bahwa $100 \%$ ibu balita yang menjadi sampel penelitian belum mengetahui penangan ketikan anak menderita demam tinggi. Hal yang sebaiknya di lakukan ketika anak menderita demam tinggi adalah mengompresnya dengan air. Air yang di gunakan sebaiknya adalah air hangat sehingga tidak akan terjadi perbedaan suhu antara suhu tubuh dan suhu air. Pengetahuan lain yang belum di ketahui oleh ibu balita adalah waktu yang tepat untuk anak mendapatkan imunisasi pertamanya. Sebanyak 95,5\% belum mengatahui waktu imunisasi pertama dilakukan, sedangkan sisanya sebanyak $4,5 \%$ telah mengetahuinya.

Larutan gula garam merupakan pertolongan pertama yang dapat diberikan ketika anak menderita diare ketikan di rumah tidak ada persediaan obat-obatan. Hasil penelitian menunjukkan bahwa masih ada ibu balita yang belum mengetahui cara membuat larutan gula garam yang tepat. Sebanyak $34 \%$ ibu balita belum mengetahui sedangkan sisanya sebanyak $66 \%$ telah mengetahuinya.

Pola asuh makan yang diberikan oleh ibu balita lebih dari setengahnya ( $52,3 \%$ ) berada pada kategori cukup baik dan setengahnya $(43,2 \%)$ berada pada kategori baik, sedangkan sisanya sebanyak 4,5\% berada pada kategori kurang baik. Hasil ini mengindikasikan bahwa ibu - ibu belum memberikan pola pengasuhan yang terbaik bagi anak balitanya. Pola asuh yang kurang memadai dapat menjadikan salah satu permasalahan yang secara tidak langsung akan mempengaruhi status gizi anak balita. Pendapat ini sesuai dengan kerangka konsep UNICEF (1990) bahwa pengasuhan yang tidak memadai merupakan penyebab tidak langsung yang akan mempengaruhi status gizi anak balita. 
Status gizi anak balita berdasarkan indeks TB/U 15,9 \% berada pada kategori stunting. Persentase stunting pada anak balita yang menjadi sampel penelitian tidak termasuk dalam kategori yang tinggi. Karena menurut WHO (1995) menjelaskan bahwa prevalensi stunting termasuk kategori tinggi apabila mencapai $\geq 40 \%$.

Walaupun persentasenya tidak termasuk dalam kategori tinggi, harus tetap menjadi perhatian karena menurut Gibson (2005) mengemukakan bahwa stunting merupakan keadaan yang terjadi sebagai akibat dari kurangnya asupan makanan, miskinnya kualitas zat gizi, tingginya angka kesakitan atau kombinasi dari berbagai faktor. Stunting yang terjadi selama masa kanak-kanak dapat menyebabkan berkurangnya tinggi badan pada masa dewasa, yang dapat berhubungan dengan berkurangnya kapasitas kerja dan pada wanita dapat berpengaruh terhadap anak yang dilahirkan, (Gibson 2005).

Uji korelasi spearman mendapatkan hasil bahwa terdapat hubungan yang positif dan signifikan antara pengetahuan gizi dengan pola asuh makan ibu balita $(r=$ $0,49 ; \mathrm{P}<0,01)$. Dapat disimpulkan bahwa semakin tinggi skor pengatahuan gizi ibu maka pola asuh makan yang diberikan ibu kepada anak balitanya akan semakin baik pula. Tingkat pengetahuan gizi yang dimiliki ibu sangat berpengaruh terhadap pola asuh makan, lebih khususnya sikap ibu dan perilaku dalam pemilihan makanan yang beraneka ragam yang selanjutnya dapat mempengaruhi status gizi anaknya. Florentino et al. (1987) mengemukakan bahwa ibu dengan pengetahuan gizi baik pada daerah perkotaan di Philipina dengan tingkat pendapatan yang rendah memiliki kebiasaan mengkonsumsi makanan yang beraneka ragam. Dengan konsumsi makanan yang beraneka ragam, kemungkinan status gizi keluarga termasuk anak balita akan baik.

\section{KESIMPULAN}

Pengetahuan gizi dan kesehatan Ibu balita dinilai dari penguasaan ibu tentang sumber pangan, kegunaan zat gizi di dalam tubuh dan pengetahuan tentang ASI \& MPASI serta pengetahuan tentang tanda-tanda dan penyebab penyakit, pertolongan pertama ketika anak menunjukkan gejala sakit, program kesehatan dari pemerintah. Dari tiga kategori pengetahuan gizi dan kesehatan 
yaitu baik, sedang dan kurang, lebih dari setengahnya berada pada kategori sedang.

Pola asuh makan dan kesehatan anak balita dalam penelitian ini diukur berdasarkan skor pola asuh makan dan skor pola asuh kesehatan. Dari tiga kategori pola asuh makan yaitu baik, cukup baik dan kurang baik, lebih dari setengah dari ibu balita termasuk dalam kategori cukup baik. Sedangkan untuk pola asuh kesehatan, dari tiga kategori pola asuh kesehatan yaitu baik, cukup baik dan kurang baik, sebagian besar ibu balita berada pada kategori baik.

Status gizi anak balita yang diukur dengan antropometri, menunjukkan hasil bahwa status gizi anak balita dengan menggunakan indeks BB/U, TB/U dan BB/TB pada umumnya berada pada kategori normal. Hanya saja pada indeks $\mathrm{BB} / \mathrm{TB}$ sebagian kecil anak termasuk dalam kategori wasting hal ini berarti telah terjadi malnutrisi pada sebagian kecil anak balita yang menjadi sampel penelitian

Uji korelasi spearman mendapatkan hasil bahwa terdapat hubungan yang positif dan signifikan antara pengetahuan gizi dengan pola asuh makan ibu balita. Dapat disimpulkan bahwa semakin tinggi skor pengatahuan gizi ibu maka pola asuh makan yang diberikan ibu kepada anak balitanya akan semakin baik pula.

\section{DAFTAR PUSTAKA}

Appoh,Lily Yaa \& Sturla Krekling.2005.Maternal Nutritional Knowledge and Child Nutritional Status in The Volta Region of Ghana. Blackwell Publishing. Maternal and child nutrition 1:100-110.

Azwar A. 2004 Kecenderungan Masalah Gizi Dan Tantangan Di Masa Datang.Jakarta. Disampaikan pada Pertemuan Advokasi Program Perbaikan Gizi Menuju Keluarga Sadar Gizi, di Hotel Sahid Jaya, Jakarta, 27 September 2004.

Engle PL, P.Menon \& L.Haddad. 1996. Care and Nutrition ; Concept and Measurement. Washington DC: International Food Policy Research Institute (IFPRI).

Florentino. 1987. Food Habits Of Households in Selected Philipine communities. Philipina : Proceedings of The Six ASEAN Workshop on Food Habits.

Gibson RS. 2005. Principles of Nutritional Assessment. New York: Oxford University Press.

Hermana. 1993. Keamanan Pangan dan Status Gizi. Widyakarya Nasional Pangan dan Gizi.Jakarta: Lembaga Ilmu Pengetahuan Indonesia. 
Jelliefe DB, Patrice J. 1989. Comunity Nutritional Assessment. New York: Oxford University Press.

Karyadi. 1985. Pengaruh Pola Asuh Makan dan Praktek Pemberian Makan terhadap Kesulitan Makan Anak Balita. Tesis Master yang tidak dipublikasikan. Bogor: Jurusan Gizi Masyarakat dan Sumberdaya Keluarga, Fakultas Pertanian.

Khumaidi M. 1989. Gizi Masyarakat. Bogor: Pusat Antar Universitas Pangan dan Gizi.

Kusumawati ,Yuli \& Mutalazimah. 2004. Hubungan pendidikan dan pengetahuan gizi ibu dengan berat bayi Lahir di rsud dr. Moewardi surakarta. Infokes 8: 1.

Moehdji S.1992.Ilmu Gizi. Jakarta: Penerbit Bhatara.

Nency Y, Muhamad TA. 2005. Gizi Buruk, Ancaman Generasi yang Hilang. INOVASI . Vol.5/XVII

Range SK, Kumar RN, Saroj B. 1997. Child Care Practices Associated With Positive And Negative Nutritional Outcomes For Children In Bangladesh: A Descriptive Analysis.Washington DC: International Food Policy Research Institute (IFPRI).

Standfield, Peggy S \& Y.H Hui. 2003.Nutrition and Diet Therapy : Self Instructional Modules Fourth Edition. [terhubung berkala] http://nursing.jbpub.com/stanfield. [1 Februarai 2008].

Suhardjo. 1986. Pangan,Gizi dan Pertanian. Jakarta: Penerbit Universitas Indonesia (UI-PRESS).

Supariasa IN. 2002. Penilaian Status Gizi. Jakarta: Penerbit Buku Kedokteran EGC.

Variyam JN. 2001. Overweight Children: Is Parental Nutrition Knowledge a Factor?.Amerika Serikat: Food Review. Volume 24

Winkel WS.2004. Psikologi Pengajaran. Yogyakarta: Media Abadi 